\title{
Travels in Bokhara
}

\section{Author(s): Willy Rickmer Rickmers}

Source: The Geographical Journal, Vol. 14, No. 6 (Dec., 1899), pp. 596-617

Published by: geographicalj

Stable URL: http://www.jstor.org/stable/1774630

Accessed: 07-05-2016 05:54 UTC

\section{Your use of the JSTOR archive indicates your acceptance of the Terms \& Conditions of Use, available at}

http://about.jstor.org/terms

JSTOR is a not-for-profit service that helps scholars, researchers, and students discover, use, and build upon a wide range of content in a trusted digital archive. We use information technology and tools to increase productivity and facilitate new forms of scholarship. For more information about JSTOR, please contact support@jstor.org.

The Royal Geographical Society (with the Institute of British Geographers), Wiley are collaborating with JSTOR to digitize, preserve and extend access to The Geographical Journal 
to fix the place, preparatory to the erection of a permanent memorial to the great traveller, which is in contemplation. Mr. Weatherley, who was the first to send us leaves from the tree, has communicated an interesting account of his more recent travels. We also expect a paper on his travels in Abyssinia from Mr. Weld Blundell.

Nor have our travellers been less active in Asia; and it seems to me that their work strikingly shows us how many limited but exceedingly interesting tracts still remain for young geographical aspirants to explore. Captain Deasy is on his way home after having examined and surveyed a previously unknown part of the course of the river Yarkand. Captain Wingate has sent us some account of his remarkable journey through China to Bhamo; and I have the great pleasure of introducing to you this evening Mr. W. R. Rickmers, who will describe to you his travels in Bokhara.

\section{TRAVELS IN BOKHARA.*}

\section{By WILLY RICKMER RICKMERS.}

A Jounney made three jears ago in the eastern provinces of Bokhara induced me to revisit the country. Accordingly in the summer of 1898 I started, accompanied by my wife and Dr. v. Krafft, now of the Geological Survey of India. $†$

I take this opportunity of thanking the Imperial Government of Russia and its representatives in Bokhara for the facilities afforded me in travelling through the Khanate. +

An officer of His Royal Highness the Amir accompanied us as guide, his duty being to see that fitting accommodation for ourselves and our horses was provided at the various halting-places on the route. The presence with us of this official was tantamount to a letter of safe-conduct, and assured for us a friendly and courteous reception at the hands of the native officials, with whom we came in contact. As he always sent a messenger in advance to announce our arrival at any station where we intended putting up, we found ample preparations made for our reception. As we approached our destination we were usually met by a crowd of gaily dressed officials, whose white turbans, p. 696 .

* Read at the Royal Geographical Society, November 13,1899. Map and diagrams

$\dagger$ My chief aim was the investigation of certain parts of the province of Baldjuan, which had been neglected by previous travellers.

$\ddagger$ For permission to visit Bokhara I am indebted to the kindness of the late General Annenkoff, whose encouragement of foreign travel in Transcaspia will make his death a great loss to those who, like myself, have had personal experience of his influence in smoothing a ray the difficulties under which the foreign traveller in these regions must labour. To the political agent, Mr. Ignatieff, and his secretary, Mr. Miller, I likewise tender my hearty thanks for the unfailing courtesy they showed me, and for the trouble they took in arranging for our comfort during our journey through the country. 
brilliant garments, and richly caparisoned steeds recalled some scene out of the 'Arabian Nights.' These, saluting us with true Oriental dignity, escorted us to their houses, where we found provision made for our comfort according to the Bokhariot's idea of a European standard. Thus, though dispensing with tables and chairs himself, he always provides these articles for his guests. Being of native manufacture, they present some truly remarkable features. In very few cases do tables and chairs correspond, and the legs of both are of most uncertain height and stability. If the table is raised some two feet above the ground, the chair generally towers some two feet above that, while if the table is an ordinary size, the chairs are frequently several feet below it. As

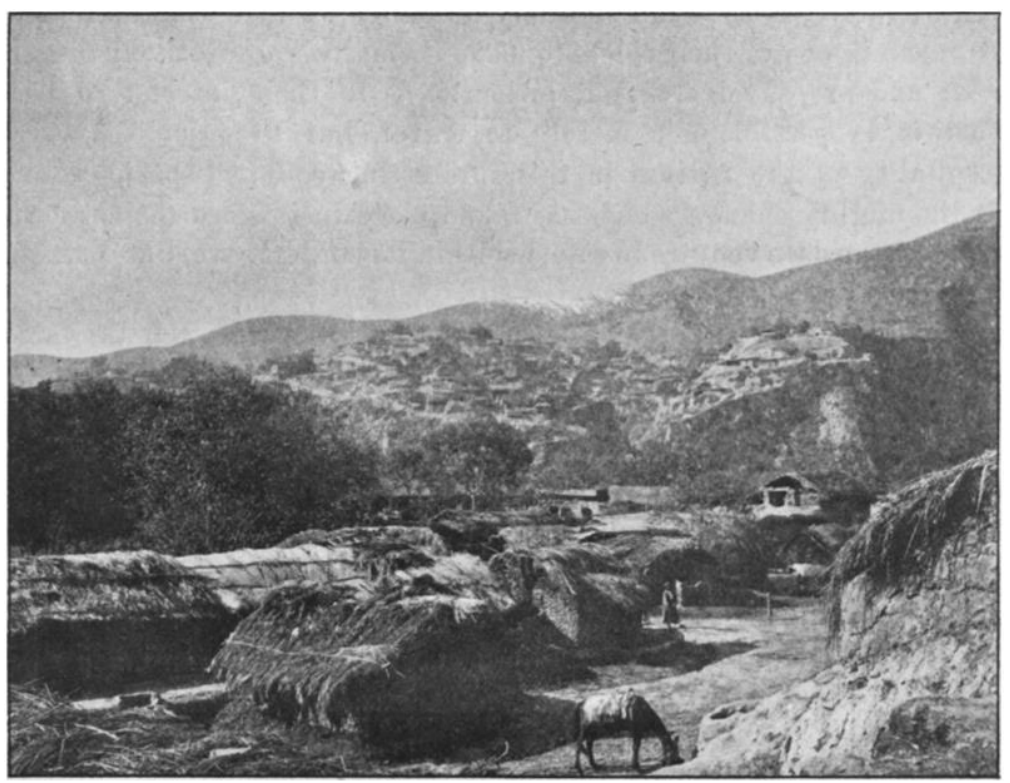

BALGNAN.

regards hospitality, the Bokhariot upholds the traditions of Oriental lavishness. The tables literally groaned under the weight of fruits and sweets of every variety. Soup, fowl, and mutton, with rice, the national fare, formed the more substantial part of the repasts, which never varied. In spite of its monotony, this diet did not pall upon us so much as might be expected. The fresh air and constant exercise probably whetted our appetite, in consequence of which we were less fastidious.

As regards our quarters, they were uniformly the best the place offered. The native bedstead, with its mattress of woven rope, can be made a most comfortable resting-place if well covered with wadded quilts and rugs. In the deliciously cool nights of early summer, the 
traveller can with safety sleep outside, the dryress of the atmosphere doing away with all danger of chill, while mosquitoes scarcely exist, save in certain localities, and noxious animals are unknown. In autumn the difference of temperature between night and day is too great to admit of sleeping outside, and one has to make the best of the native dwellings. Air is generally to be had in abundance, as the doors seldom fit, and cracks and crannies in the wall provide sporadic ventilation in unexpected quarters. These same crannies afford a hiding-place for certain minute insects, which have a knack of making their presence felt while they themselves manage to remain invisible.

Beyond these minor discomforts, there is little to deter a traveller who enjoys sound health from making a similar journey. Of attacks from the natives there is absolutely no danger. The people are quiet, too much in awe of their rulers to make themselves aggressively disagreeable; and are effusively polite when it is to their interest to be so. That it is possible not merely to travel, but to enjoy the private hospitality of the natives in this interesting country, speaks volumes for the mighty change which has taken place in it since the days when no European dare venture in safety within its borders save, like Vambéry, under cover of a perilous disguise.

Our little caravan, consisting of some twelve horses, left the famous old Mohammedan metropolis on June 27. The first part of our journey, as far as Karshi, lay along the well-known trade route to the south. Soon after leaving the Russian town of New Bokhara one enters a region of sand-dunes, which, alternating with stretches of steppe, continues as far as Kwaja-Mubarak. There it gives place to partly cultivated steppe until Kazan is reached, where begins the luxuriant belt of gardens surrounding Karshi.

The contrast between this fertile oasis, in which groves of mulberry, apricot, and apple trees refresh the eye, and the dreary desert of the first two days' march can be more easily imagined than described. The traveller in these desolate regions is, however, not without provision for his safety by the way. At Karaul, the first station reached after leaving Bokhara, there is a fine reservoir covered with a large cupola of brickwork. Close by, the ruins of an imposing caravanserai rtcall the efforts of former rulers to mitigate the dangers of desert travel. These and similar remains elsewhere along the road are ascribed to Abdullah Khan, an Amir of Bokhara during the sixteenth century, and one of the few historic names still lingering in the native memory as associated with the past greatness of the country.

Karshi, the first town at which we halted, boasts a certain antiquity, and, though far inferior to Bokhara in point of interest, exhibits in its bazaar-life similar features to that of the capital. Its beautiful gardens with their rich foliage add a charm to the place which Bokhara has not in the same degree. From the roofs the town appears embosomed in trees. 
At Guzar, some 30 miles beyond Karshi, we leave the great Transcaspian plain and reach the first low spurs of that vast expanse of mountains which continues without a break to the great plain of Northern India.

Our approach to higher ground did not bring us that relief from the heat for which we had hoped. The vegetation of the hills at this season is parched and dried up, and the rocky walls of the valleys beat back with redoubled vehemence the fierce glare of the sun. The prominent feature of this belt of outlying hills is the loess. This geological formation dominates the landscape as far as the high alpine regions. Its varied aspects, deep chasms, and steep banks constitute

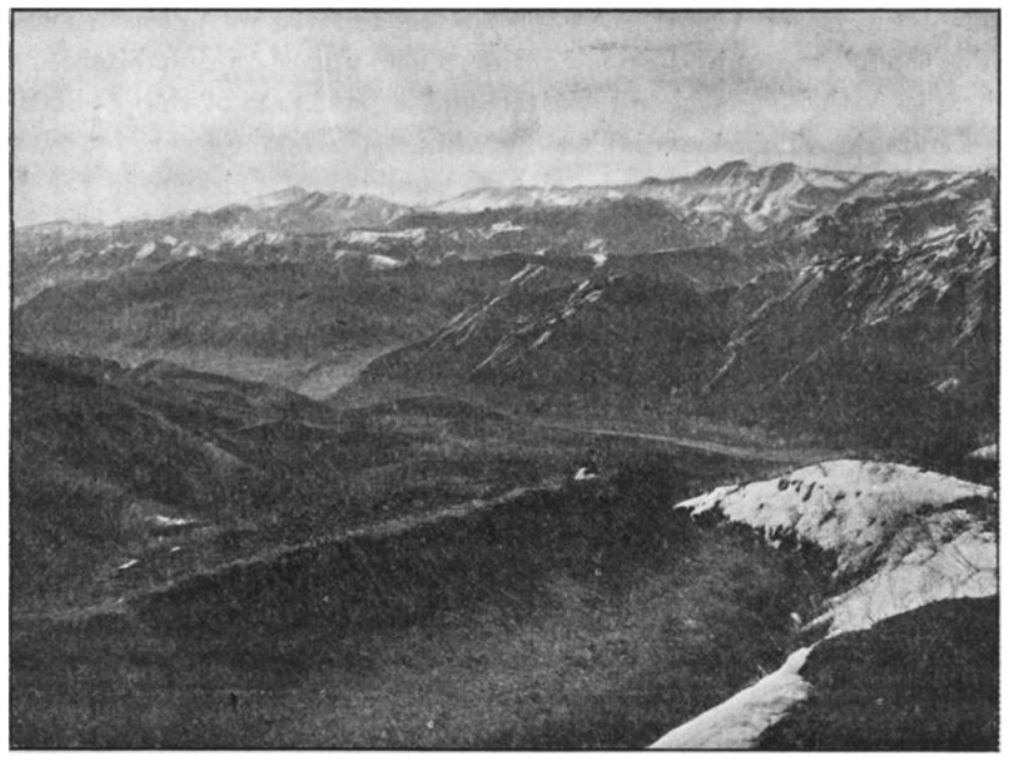

THE YAKH-SU VALLEY AND CONGLOMERATE MOUNTAIN, FROM THE PASS BETWEeN KHOVALIN AND SARIFUL.

a characteristic scenery of their own. A sea of slippery yellow mud in rain, the source of volumes of impalpable dust in dry weather, it makes itself but too familiar with the clothes, eyes, ears, and mouth of the traveller.

Here and there rocky crests rise out of the undulating loess. Through one of these lies the famous defile known as the Iron Gate, and mentioned by the early Chinese traveller Hiuen-Tsang (about A.D. 630). This remarkable sandstone gorge, which cleaves the mountain from summit to base, is about a mile long, and at times only a few paces in width. Its mighty cliffs, hewn and carved in bizarre fashion, tower in places to a height of $600 \mathrm{feet}$, and are rendered the more 
impressive and picturesque by reason of the windings of the gorge. In the winter a stream flows through the chasm, which is then impassable, and the travellers circumvent it by a path over the mountain.

Passing through Darbend and Baisun, we descended into the swampy valley of the Surkhan, which we followed as far as Karatagh. Here we stayed a few days to give the horses rest.

Karatagh, which lies on the banks of a rushing river at the point where it leaves the Hazrat Sultan mountains, is the summer residence of the Kush-Begi of Hissar, the most important dignitary of the Khanate after the prime minister of Bokhara. He is the governor of the entire eastern half of the Ameer's dominions, and invested with great privileges, having power over life and death. During the winter he lires at the ancient capital of Hissar. At the approach of the warm season, when malaria and mosquitoes render the place almost uninhabitable, he migrates with his goods and chattels and a great part of the population to Karatagh. This biennial exodus almost clears the town, for everybody from the highest official down to the meanest prisoner in the jail follows his master. Not only does the Kush-Begi move all his valuables: from one capital to the other, even the lumbering cannon, of which he can muster two or three specimens, are dragged in the train of the hundreds of camels employed for the removal of bis household. Many of the animals literally groan under the weight of the bags filled with the hard cash which forms no inconsiderable part of his treasures, while others have the lighter burden assigned them of carrying the numerous inmates of his harem.

While at Karatagh we made an excursion to the Timur-Dera-Kul, a small lake to the north of the town at a height of 8000 feet. Wefollowed the valley of the Karatagh river, which winds through magnificent sceners, precipitous mountains hemming it in in parts. Vegetation, though scarce, was never entirely absent. A species of briony twined itself round the gigantic boulders strewing the river's edge, while willow and mulberry trees frequently occurred. At the village of Khaki-mi we stopped for the night, our quarters being the portico of a mosque, the only shelter available. The scene was a very fine one, the pillars of the mosque serving as a frame to the mountains which towered aloft in front of us, the moonlight turning their snowcrowned summits to sheeted silver.

From Khaki-mi on the following day we rode on to the Timur-DeraKul. Here Nature was more prodigal with her gifts than in the parts we had hitherto visited. Round the water the walnut, the mulberry, and the willow abounded, with flowers of every hue and variety akin to many European species. The water is of the most exquisite bluishgreen tint.

The lake lies north-east by south-west, and is fed by two streamsthe Yangi-lik on the east, and the Ak-tash on the west. The dam at 
its lower end is an old moraine, and the overflow produces a pretty cascade. It was in this neighbourhood that we saw the nearest approach to a forest during the whole of our sojourn in Bokhara, for the natives with their primitive tools play havoc with any trees within reach, ruthlessly destroying as many as two or three of them in the attempt to obtain a single plank. Here and there shading their courtyards are to be found venerable trees, generally planes; but these are exceptions, the country as a whole being remarkably bare of the more stately representatives of the vegetable kingdom.

From Karatagh we had each day to struggle over some rugged mountain pass, and we successively crossed the valleys of the Kafirnighan,

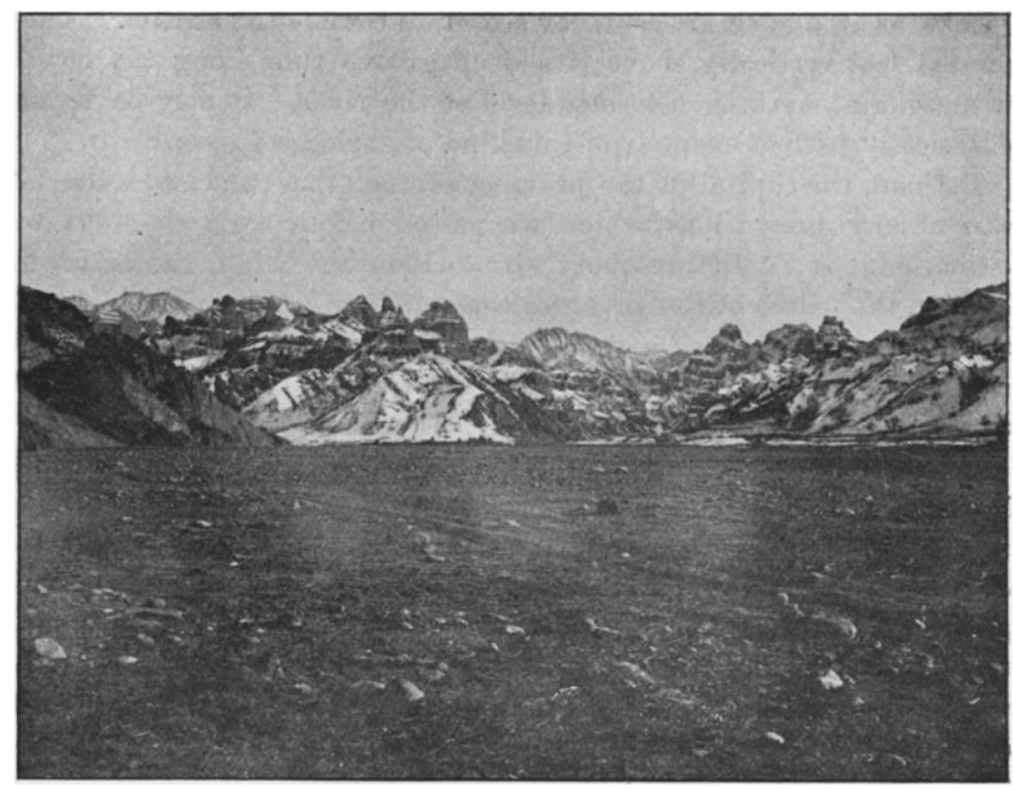

A SIDE VALLEY OF THE YAKH-SU.

the Vaksh, and the Kizil-Su. Bridges in this country are few and far between, and the Amir's highway is often deflected for a day's journey owing to their scarcity. Most of these structures, constructed on a primitive form of the cantilever principle, are unable to resist the onrush of the spring floods, and have to be built anew each year. A notable exception is the bridge over the Vaksh. Between Norak, famous for its salt-mines, and Tut-Kaul this river runs through an extremely narrow valley. Here the path skirts the rim of precipices, over which a single false step on the part of the horse would suffice to fling him and his rider into the turbulent waters below.

At the spot where this river, equal in volume to the Thames at Kew, 
is pent into a rocky chanvel 8 feet wide, the native engineers have seen their opportunities. A few beams are sufficient to span the cleft, while a thick hedge of interwoven branches screens the giddy depths from the traveller's eyes. A gate on the bridge marks the frontier between the provinces of Hissar and Baljuan. In ancient times, when constant wars were waged among the minor states, many an expedition must have been frustrated at this point.

Another remarkable phenomenon in the Vaksh valley is to be seen just above Tut-Kaul, on the right bank of the river. This is an embankment of solid rock formed by the outcropping surface of a stratum of limestone. It runs in a perfectly straight line for a distance of several hundred feet, and such is its smoothness and regularity that it looks as if human art bad devised it to confine the stream. A few hundred feet vertically above it a deep groove runs along the face of the mountain, marking a former level of the river. It may be termed a classically perfect example of this kind of geological record.

Baljuan, the capital of the province of the same name, was the last town of any pretensions which we passed before we arrived at our destination. It is picturesquely situated on the high banks of the Kizil-Su, the palace of the governor commanding a fine position on the summit of a loess cliff. On market days the population overflows into the river-bed, a vast stony plain reduced to an almost dry state during the summer.

Here, in contrast to the flat mud housetops prevailing in other parts of Bokhara, we have sloping roofs thatched with reeds. The town possesses a native garrison, which entertains the populace with martial music and military evolutions every morning and evening. Their appearance in a garb which strives to imitate Russian military costume has something of the ludicrous about it. It is one of the many illustrations of perversion of taste which contact with Western civilization so often produces in the Oriental. Of a piece with this is the red cotton with which rcoms prepared for the reception of Europeans are frequently covered in place of carpets.

Crossing a watershed into the valley of the Yakh-Su, we bade farewell to the regions of sand, steppe, and loess, and entered the subalpine level. From the summit of the pass between Khovaling and Saripul we had our first view of that wonderful mountain system of the "conglomerates" of East Bokhara.*

* This region has rarely been visited, and I have not been able to find more than a passing remark on the Yakh-Su valley. The reason for this is that the eastern provinces of Bokhara have only in comparatively recent times received the attention of explorers.

The early reports of Hiuen-Tsang and of the Buddhist monk Syan-Dzan down to those of Forsyth and Trotter were chiefly based on second-hand information. Then began the great activity in the countries west of the Pamir, and associated with the 
Ascendirg the Yakh-Su valley, we established our headquarters on one of its tributaries - the Safet-Darya (White river), which joins the Yakh-Su just below the village of Talbar, marked on the Russian map, and mentioned by Regel.

The conglomerates cover an area of about 800 square miles, disposed in a long strip between the rivers Vaksh and Panj, with a strike from north-east to south-west. They show distinct stratification. Dr. v. Krafft ascribes them to the tertiary period.* The stones composing them are chiefly crystalline. The greatest thickness of the formation may be said to be at least 4000 feet. The rounded forms of the soft conglomerate are easily distinguishable from the jagged and fantastic outlines of the bard zone. The highest peaks typical of each category are respectively Hazrat-Ishan (13,000 feet) and Kuch-Manor (10,500 feet). Both of these were constantly visible from our quarters in the Russian colony of Safet Daria. The scenery is wild and weird to the last degree. An intense solitude pervades the valleys, where Nature is so sparing that scarcely a living creature is to be seen. Serrated ridges and gaunt pinnacles stand out black against the blue sky.

In this district we spent several months. By the time we arrived the vegetation had quite dried up. As we climbed the slopes, the crackling skeletons of umbelliferous giants punished our intrusion with

names of Oshanin, Severtsoff, Regel, Fedshenko, Ivanoff, Pokotslo, Yonoff, and others. Many of the results obtained by these travellers are recorded in Mr. Rob. Michell's paper (Proceedings, 1884), and in Mr. Delmar Morgan's able résume on the recent geography of Central Asia (Supplementary Papers, 1885).

The first who actually visited this district was the Russian botanist, Dr. Regel (1882). A translation of his letter from Kala-i-Khumb is to be found in the Proceedings of 1882 . In the following year le visited Shugnan, accompanied by Kossiakoff (Proceedings, 1886). From his original report I gather that he journesed through the valley of the Yakh-Su, and this is corroborated by the map showing his route (Proceedings, 188t). All the other travellers whose reports I have read have avoided this valley.

The best map is that of the Russian General Staff, which gives a fairly accurate idea of the topograpby of these parts, and on which the river is called Yakh-Su. All previous maps have Ak-Su. There is no other information beyond that conveyed by Regel's account and the various maps. The peculiar and remarkable features of this region seem to have escap $\epsilon$ d observation.

To those who consult the maps in the Society's publications a few hints may be uscful. On the map of Pamir (Proceedings, 1884) Saripol is easily found; Khovaling is called Khalaling. On the map illustrating Kossiakoff's route (Proceedings, 1886) the name Shignan occurs just below that of 'Talvar (Talbar). The little river immediately to the south of Shignan is the Safet-Darja. Shugnan (as the latest Russian spellings has it) is a subdivision of the district of Talbar, and must not be confused with the province of Shugnan; it is not a single village, but the collective name for a number of settlements. The same map has Tavaling (instead of Khovaling) placed to the right of the spot where the Ak-Su begins to be represented by a dotted line.

* Dr. v. Krafft will give the results of his geological investigations in the forthcoming publication of the Vienna Academy of Sc:ences. 
showers of dust. Only where there is a constant trickle of water green patches may be seen throughout the summer. In the higher regions, of course, the meadows remain green a long time. Trees are scarce, but in the more secluded valleys apologies for woods manage to exist, to the great delight of the lover of nature. The pine is represented by the thuya, which thrives on scanty soil, and is satisfied with a precarious foothold on the brow of precipices, safe from the ravages of man.

The Yakh-Su valley is the home of majestic walnut trees. With their gnarled stems and spreading foliage they are the pride of the

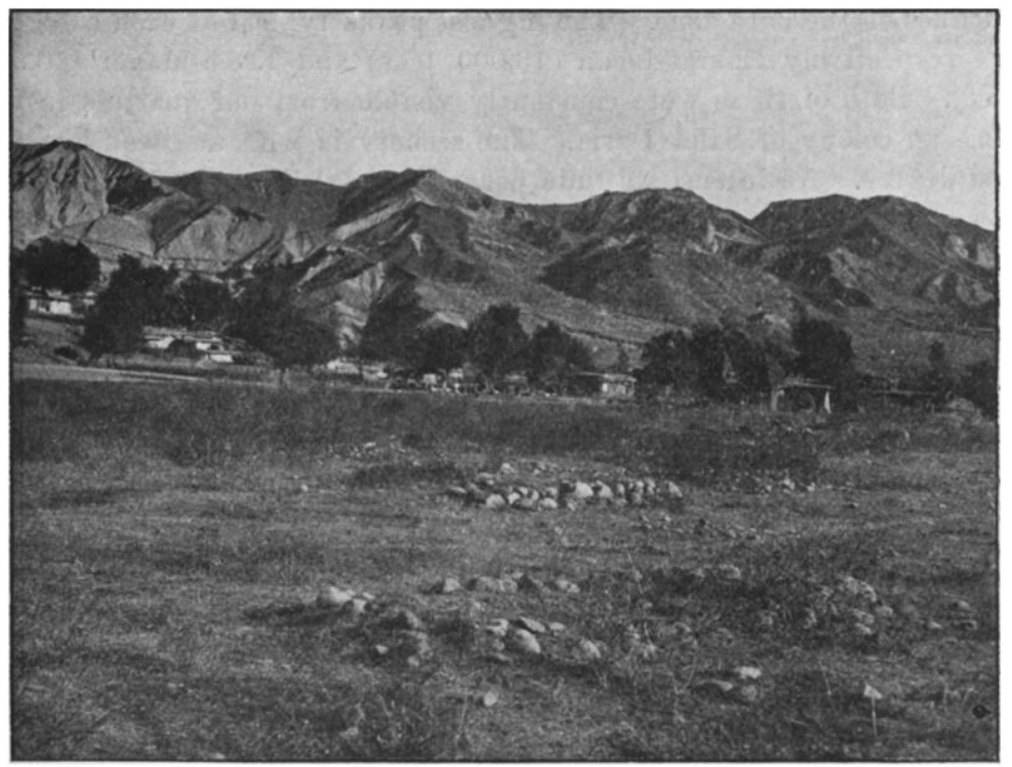

RUY DASHT, ON THE SAFET-DARYA.

hillside. Unfortunately, some years ago an Armenian vandal destroyed many thousands of them for the sake of their grained knots.

As to the animal world, I only observed two wild mammals-marmots and a species of mountain sheep. I once stalked and wounded one of the latter, but it got away among the inextricable maze of gullies and ledges. I believe it was Ovis arkhal. The habits of the marmots are instructive from the point of view of animal economy. The beginning: of their hibernation is determined by two different factors, the dry season and the cold season. Around the Russian village, at a height of 6000 feet, their piping is continually heard in spring, but they do not show themselves any more at the entrances of their subterranean abodes after the middle of August. Two thousand feet higher their food is green much longer, and there they do not retire before the 
beginning of Siptember. At an altitude of about 10,000 feet only the cold will send them to sleep, because the water trickling from the patches of snow keeps little kitchen gardens going for them.

The same causes influence the migration of wild and domestic sheep. In September I was unable to discover any arkhal about Kuch-Manor, where they usually abounded. They would be found around Hazrat Ishan if it were not for the shepherds, who infest this mountain with their flocks, gradually going higher and higher until everything is eaten up. Then the large herds of fat tailed sheep are driven downwards from all directions, and caravans of thousands of them throng the narrow paths. Their winter quarters are the irrigated lowlands

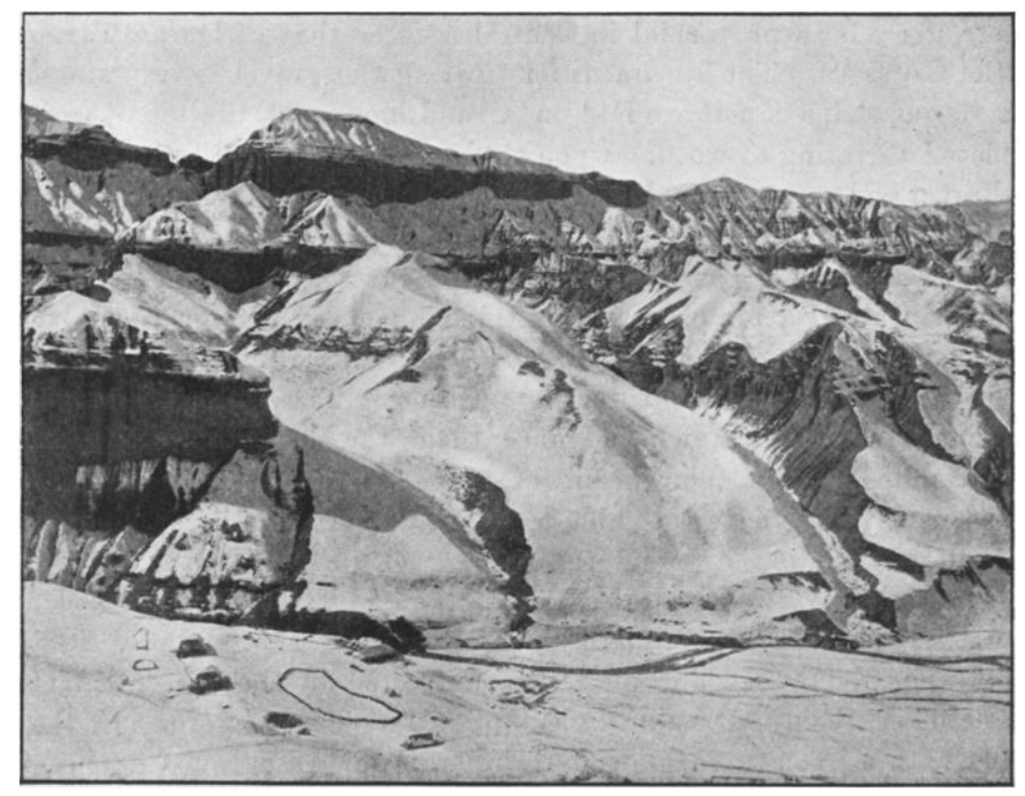

THE RCSSIAN COLONY OF SAFET-DARYA.

of the Amu-Darya, where food is found all the year round. Thus the sheep are always on the move, and the natives only keep a small stock in their villages for immediate wants.

There is one glorious pasture, however, which is safe from the cattle of man. The mountain immediately to the west of Kuch-Manor has a flat top offering an undulating surface of about half a square mile, which is conspicuous from Safet-Darya, and which changes its colour from green to brown as the months succeed each otber.

When Dr. v. Krafft and myself reached the top of Kuch-Manor after some unsuccessful attempts, we also passed over this secluded paradise, which the natives have never been able to enter. Towards 
all sides steep rocks descend from it, and the marmots that stare at you till you might almost seize them, and the broad tracks traced out by the hoofs of mountain sheep, show that here the wild animals feel secure, amid an abundance reserved for their exclusive use.

They are to be envied when compared to the ragged and wretched human population of the valleys below, which raises an uncertain crop of corn on the mountain slopes, and is mainly dependent for its livelihood on the gold-washing industry.

The precious metal has been obtained from this region for centuries, as is shown by the old heaps of tailings at higher levels than those frequented by the present natives, who only work near the water. Legend associates these traces of old workings with Chingiz Khan, whose name is as proverbial in Central Asia as that of Queen Tamara in the Caucasus. The apparatus for treating the gravel is very simple. A series of strips of felt are laid on a sand incline, at the top of which is placed a grating of wood. Upon this grating a shovel full of gravel is thrown and water poured over it. The fine material is washed down and the gold caught by the felt. All gold in the shape of dust is lost, some of the rougher particles only being secured. By this process not more than about a ton of gravel is treated per day. Groups of about five men work together. Two dig out the material, one carries it to the water, and two attend to the washing. These men are all in the hands of sweaters, who advance them the necessaries of life at extortionate interest, and keep them continually in their clutches. Consequently they never are able to attain comparative prosperity, and do as little work as they can.

The yearly gold output of East Bokhara is variously estimated at from $£ 20,000$ to $£ 30,000$, a mere trifle considering the potentialities of the alluvial deposits. The quantities extracted by the natives in the course of centuries have hardly encroached upon the store, and they are as nothing compared to what Europeans might produce here in a few years. So far the proportion of gold in the conglomerate itself has not yet been established, the fluviatile deposits resulting from its disintegration offering greater advantages for mining purposes. The original birthplace of the gold is of course to be sought for in the surrounding crystalline ranges forming the banks against which the conglomerates were deposited. The gold occurs exclusively in tablet form, grains and nuggets being nowhere found. The largest piece we ever saw weighed about half an ounce; it is $92 \cdot 7$ per cent. fine. We have made extensive investigations into the distribution of the metal, and $I$ here give some of the results. Two facts of general experience were at once apparent: the richness of the sands increased with the depth, and the gravel terraces on the banks were richer and contained coarser gold than the actual river-bed.

The alluvial deposits are clearly stratified, and the corresponding 
layers can be more or less easily identified at distant spots. The top layer is about 6 feet thick, and contains on an average 8 grains of gold to a ton of gravel. Below this lie 19 feet of gravel with hardly any valuable contents. At this depth large blocks are encountered, forming a sort of stratum of their own, as if to protect what lies under them, namely, a blackish sand, which at the beginning yields 24 grains, and from which some 6 feet lower down we were able to extract nearly a quarter of an ounce to the ton.

The bed-rock lies at least 20 feet deeper-that is to say, at least 45 feet below the surface. A native claimed to have reached it once. The people burrow in the ground like moles, and produce what are known Kuch-Mano:

Platexu.

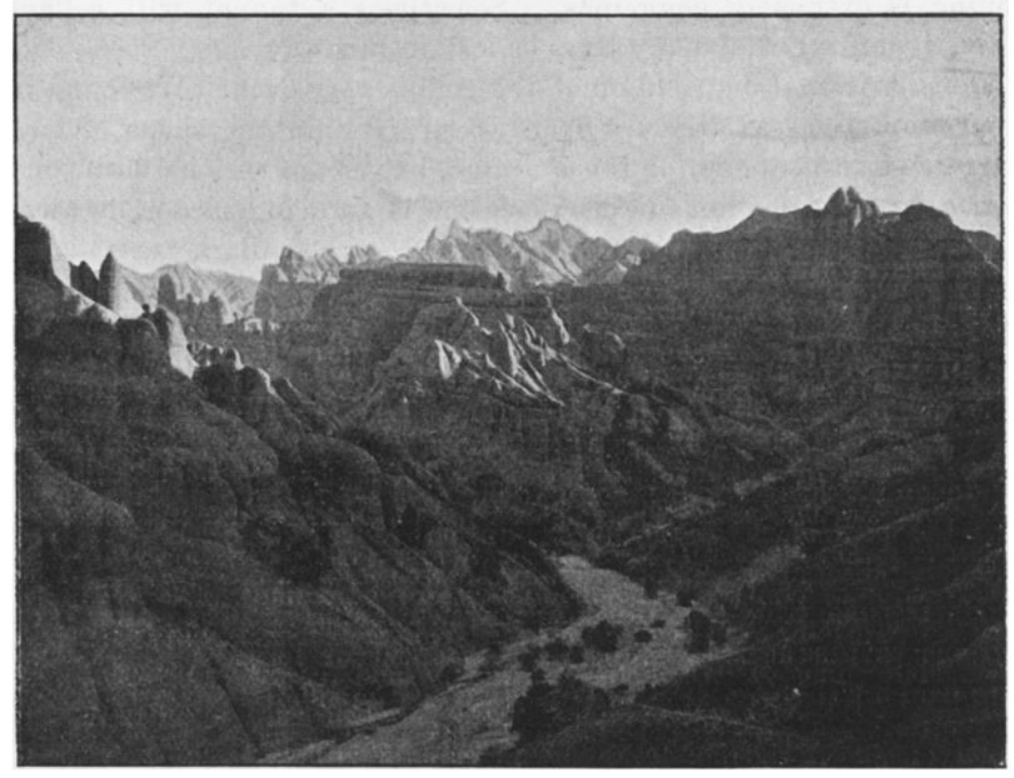

DANDUSHKA-BEND.

in America as coyote-diggings. These tunnels are about 4 feet high by 2 feet, and go down to a considerable depth; but there being no ventilating-shafts, the farthest point that can be attained depends on the possibility of being able to breathe. As the strata are concave, getting thinner as they rise up the mountain-side, they can be successively intersected at any angle. The native shafts are directed towards the mountain, and descend steeply until the rich layer is struck, which they follow until the primitive oil-lamps cease to burn. Thin, sickly looking boys carry out the earth on their backs. They are half naked, and the few rags that just manage to stick to them are drenched with the muddy water which oozes from their baskets. 
The level of the underground water coircides with that of the rich gravel, and is got rid of by what is technically termed a tailrace. Its initial stage is some excavation near the surface, from which the water is drained by a trench. As the work progresses up-stream, the canal is continued almost horizontally, thus cutting deeper and deeper into the rising ground. The canal is protected with flat stones or boulders, and the tailings of the advancing works are used to cover it.

From a shaft that is sunk near such a canal a short passage is run to connect it, the miners being guided by the sound of the running water. In this way these subterranean drains grow section by section, some of them being over a mile in length. The native method of mining is extremely dangerous. Sometimes a tunnel will collapse without warning, and many lives be lost in this way.

The horizontal distribution of the gold is very even. We found the same proportions at different spots. Surprises in the shape of large nuggets or nests are out of the question, but so are serious disappointments, for what one finds in one place one is sure to find 5 miles away, if only the general conditions of the localities are similar.

If it were not for the money-lenders and official blood-suckers, the native population might attain a flourishing condition. It has, however, lost all ambition and all forethought for the future. Though food is easily and cheaply obtainable from the nearest market towns, the natives are too poor to lay in stores, but live precariously from hand to mouth. Famines are frequent, and then the population is reduced to bread made from the pith of the asafoetida, while caravans laden with grain may be passing along the Yakh-Su on their way to Darwaz.

During our stay at Safet-Darya we made frequent exploring excursions to the surrounding mountains and valleys. Several visits were paid to the top of Hazrat Ishan. A fine ridge 7 miles in length, descending gradually from the summit, affords a splendid line of ascent. We used to ride for a height of 11,000 feet, completing the rest on foot. I give the height of the mountain as 13,000 feet, this being about 300 feet below the mean of the numerous readings from my five aneroids. All other heights have been treated in the same way, thus avoiding all exaggeration. On the south-eastern side the mountain is steep, owing to the projecting ends of the uptilted strata.

The opposite slopes are covered by the only glacier of which the conglomerates can boast. It is one of the second order, reaching down to a level of about 11,000 feet. Two hundred feet from the upper rim a deep bergschrund cleaves it from one side to the other, and below this several small crevasses occur. The one terminal moraine which I had occasion to inspect, and which is a little to the right of the main ridge of the mountain, is a high mound of débris, forcing the glacier to split at this point. Similar examples on a larger scale are offered in the Alps by 
the Macugnaga glacier and the glacier the Miage, which also have obstructed their own way.

The most noteworthy peculiarity of this moraine, however, lies in the fact that it consists of rounded smooth stones instead of angular fragments. For a glacier working on conglomerate, the production of such a moraine is of course quite logical, but it strikes one forcibly as one of those quaint possibilities which the fertile imagination of nature loves to invent. A sharp ridge which begins at the randkluft parts the

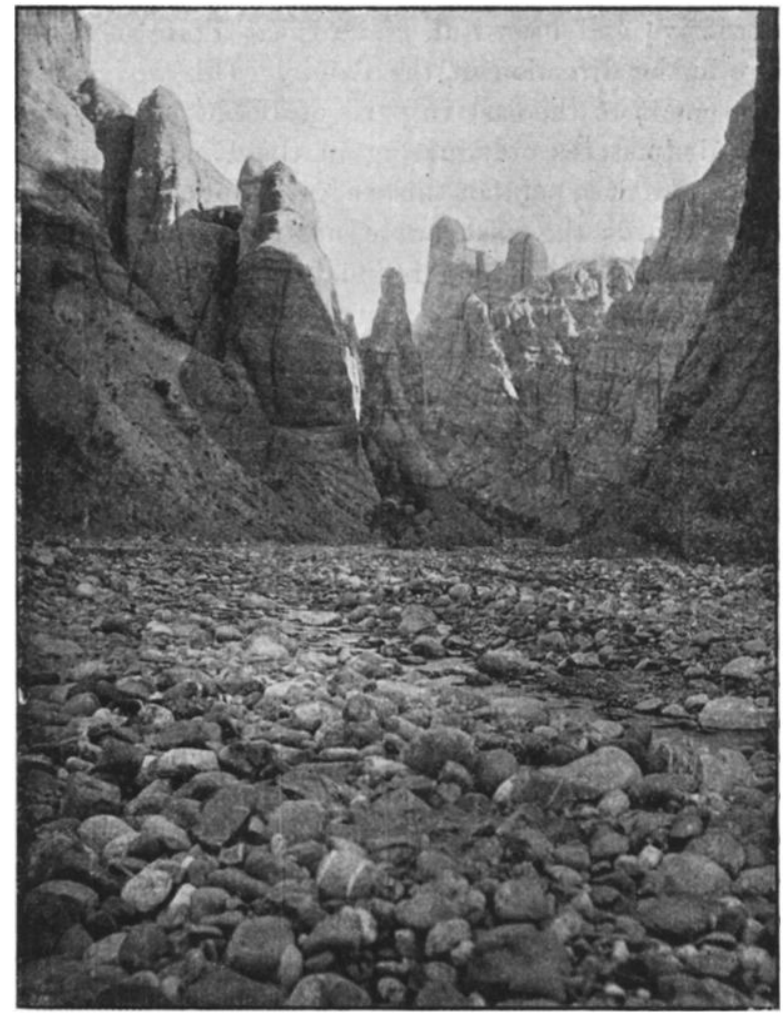

A GORGE.

glacier into two branches. The longer one joins the névé in the col between Hazrat Ishan and the peak to the north-west. The shorter branch leads to the moraine which I have described. The snow-line I consider to be at about 11,000 feet.

The name of the mountain is derived from a Mohammedan saint, who is said to have converted to Islam this part of the country.* A minor

* This saint is also known as Hazrat Ali, and as another locul name for the same person, that of Sha-i-Mardan was quoted to me. The mountain, in spite of its comparative insignificance among the great and numerous mountain ranges crowding the

No. VI.-DECEMBER, 1899.] 
saint, viz. a mullah from one of the villages, is buried on the top; a heap of stones and the usual pole hung with rags indicate the spot. Native officials in their gorgeous raiment may now and then be seen wending their way to the summit, bent on a pilgrimage to the holy grave. Any one not acquainted with the real reason for such bodily exertion on the part of these languid gentlemen, must rub his eyes and ask himself if he were not dreaming-an Oriental dignitary as a mountaineer is too strange a sight.

Owing to the particular position of Hazrat Ishan, the view from the top is instructive and beautiful. The great Transcaspian plain sends out a wedge in the direction of the Pamir. This wedge, which on the whole corresponds to the eastern parts of Bokhara, leads right into the great mountain fastness culminating in the Himalajas. Now, Hazrat Ishan is situated at the point of this wedge. Not a single snow-mountain is to be seen towards the west, but eastwards there is nothing but an ocean of ice and snow sweeping round in a huge curve from north to south. Thus Hazrat Ishan lies exactly at the apex of that semicircle which forms the boundary-line between eternal snows and the hills below the snow-line. We caught many a glimpse of the Hissar range, the Alai, Peak Kaufmann, the Pamir, and the Hindu Kush. Kuch-Manor we also climbed, and spent many exciting and enjoyable hours in its dark gullies and on the faces of its sunlit cliffs.

During our outings we never felt the least anxiety with regard to the weather. When day after day we beheld a blue and cloudless sky, we at last took it as a matter of course, and were never deceived. For a mountain region the regularity of the climate during the summer is astounding, and my table of barometrical and thermometrical readings is elcquent on this point. From the beginning of July to the end of October we had not a single drop of rain. In November, however, the Italian landscape changed into a Scotch one, mists came rolling down from the slopes, and snow began to fall. Until March these valleys are buried in snow, and almost inaccessible. Then comes a period of continual rain, which lasts till May, when the sun begins to battle effectually against the clouds.

I shall now deal at some length with the physical geography of a topographical feature which attracted my attention, and to the investigation of which I devoted some considerable time. So far I have been unable to find any mention of a similar phenomenon in the literature on the subject.

For want of a more elegant name, I shall let it be known as the

maps, seems always to have attracted much attention. For this its sanctity is partly responsible; moreover, its height and comparative isclation makes it very conspicuous to any one approaching from the west. On the map of the Pamir (Proc., 1884) it figures as Kazret-Imam, and on the one accompanying Mr. Morgan's paper as Hozret-Imam, whereas the most recent Russian variant is the cne adopted by me. 
"Dandushka Barriers." As the word suggests, they are a series of obstructions, and as such they cannot fail to impress their existence upon any one wandering along the valley of the Dandushka river. They may be a joy to the geographer, but a different opinion is entertained by the horses which have to carry the said gengrapher across.

An idea of the loculity may be formed by a glance at the map. Running from south to north in a fairly straight line there is a long and narrow valley. In its upper portion flows the river Dandushka, but its lower half is claimed by the Safet-Darya, which enters it from the east. Then, again, a river from the right, the Yakh-Su, asserts its supremacy

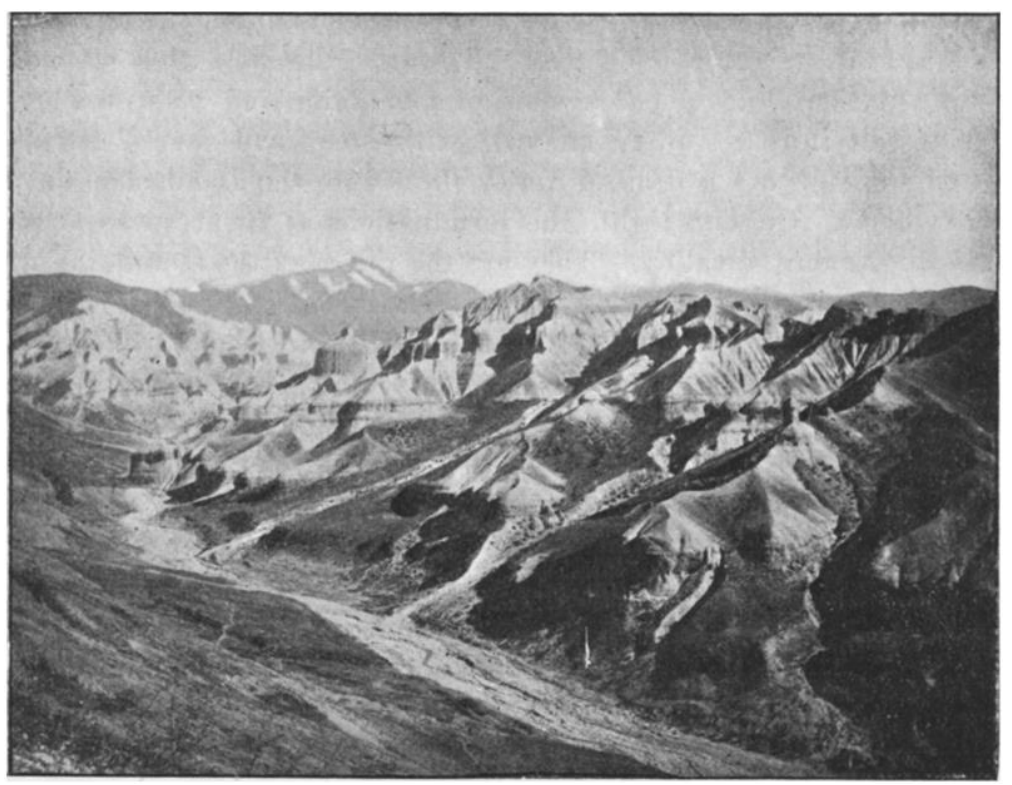

SAFET-DARYA VALLEY, WITH HAZRAT-ISHAN.

and caries the collected waters to the Kizil-Su, which takes them to the Amu-Darya, the hydrographical omega of these regions. Thus we observe that all the watercourses which come from the east successively give their name to the one that comes from the routh. First of all we have the rivulet $a b$, of which $I$ was not able to ascertain the native name; then the Dandushka ( $c d$ is very small), the Safet-Darya; and finally the Yakh-Su, which draws a line, as it were, and stops the continuation of the series.

For the sake of convenience, I shall apply the term Dandushka valley to the entire channel from the Kuch-Manor to the Yakh-Su. I am thereby enabled to express by one word a conception which 
represents an organic whole. Its beginning is where $a b$ turns to the north, viz. already above the real Dandushka river and the end where the valley loses its individuality by merging into a larger one. Of course there is not the slightest intention of changing the native nomenclature, which is based on the relative quantities of water, which therefore, as will be seen, also has an important indirect bearing on the matter.

The length of the Dandushka valley is about 10 miles, the height above the sea-level is about 5300 feet at the lower and 7000 feet at the upper end. The fall is three per cent., and very regular; water is discharged into the Yakh-Su at the rate of 50 cubic feet per second. The bottom of the valley is a flat expanse of gravel bordered by the mountain slopes.

Looking along the valley, we see parallel to it on our left a ridge with a mean height of $8500 \mathrm{ftet}$. Towards the west this watershed sends out a well-developed system of mountains and valleys, whereas on our side it is an unbroken wall with steep and short buttresses. From this side not a drop of water flows into the Dandushka during the summer. On our light, the terminations of great spurs abut at right angles on the valley. They are the ridges of the mountain group which is dominated by Hazrat Ishan.

The whole of the Dandushka ralley lies in these parts of the conglomerates where the strata are horizontal. To the south of the stream $a b$ and along the Yakh-Su the strata are inclined. The extreme ends of our line, therefore, touch the boundary of the geologically undisturbed region of the conglomerates.

Placed at the point where Dandushka and Safet-Darya meet, the spectator will see stretching away from him towards the south an imposing avenue of towers, buttresses, and domes carved out of the solid rock. If the light be favourable, he can follow with his eses for 5 miles, some of the harder bands which jut out cornice-like from the wall above him, and which he can still recognize as thin black strips in the far distance. Down-stream the material is softer, and has not given the same opportunities to the chisel of Nature.

On the map I have indicated by a dotted line the flat bottom of the valley, which is a gravel plain with a uniform fall of three per cent. At several places, indicated by Roman figures, this level is narrowed in so as to form a series of sections similar to a string of sausages. The cause of these contractions are the barriers. The first of these lies just above the Dandushka river proper; number III. is a double bar. If one examines one of these structures from one of the intermediate basins, it presents itself as a high dam stretching from bank to bank. Near the mountain a narrow cleft gives passage to the river. Inside this cañon on both sides are smooth walls of hard conglomerate, and the same material is discovered below the water after the superficial bed of gravel has been cleared away. 
The average height of the barriers is 50 feet. No. 1 is about 27 feet high ; all dimensions of the barriers increase as one proceeds downstream. The uppermost terrace of $\mathrm{V}$. is 100 feet above the water. The lowest point is at the rim of the gorge, whereas one must not take the greatest elevation at any point more distant from the cañon than the middle line of the valley, for the connection of the barrier with the mountain is drawn out into long curves which do not admit of establishing a sharp line of demarcation.

As to the breadth of the dykes-or, what is the same, the length of the cañons-it likewise increases as one descends the valley, and the passage widens out in proportion. A man on horseback can just squeeze

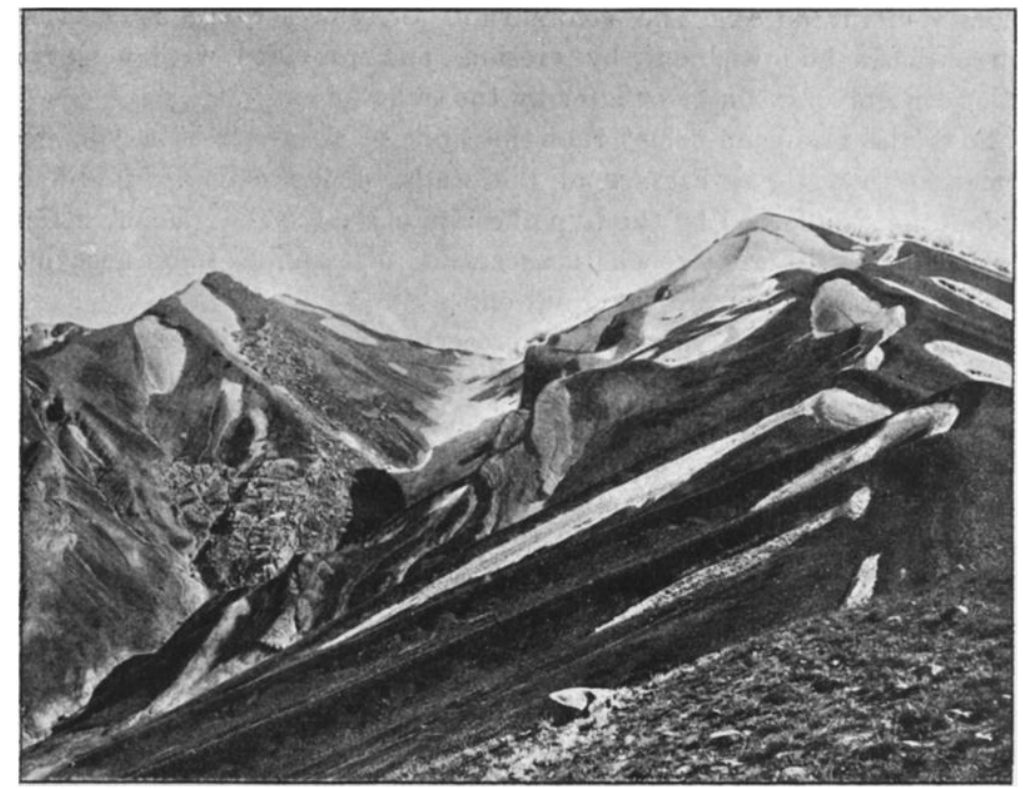

HAZRAT-ISHAN.

himself through the cleft of No. I., which is 40 feet long; IV. and V. combined form a concrete canal half a mile long, 12 feet wide, and from 40 to 50 feet deep. With the single exception of bar 1 , the cañon is always on the left side of the valley, and close to the bank. On entering and.on leaving the dark defile, the river always has level ground on its right, steep slopes on the left.

The various geographical features which I hare outlined so far may not seem to present anything extraordinary in themselves, but they become interesting when brought to bear upon each other with regard to the origin of the Dandushka barriers. How have we to account for the level sections? for the cañons, etc.? Were there lakes? 
Was it ice-work? Have we to consider upheavals, subsidences, or volcanic forces? If the first impression is not subjected to scrutiny, the casual observer will, in nine cases out of ten, take it for granted that the barriers are solid rock throughout, their outward appearance being easily accounted for by a superficial csvering due to disintegration. The aspect of the cañon sawn through the living rock leads, by an unconscious process of reasoning, to the apparently simple and satisfactory conclusion that there exists a homogeneous continuity to the other side of the valley. As long as this erroneous view prevails, further inquiry confronts one with a puzzle. The surroundings are entirely of hydrodynamic origin ( $\mathrm{I}$ include possible glacier work). Everything in the locality excludes volcanic agencies or the least tectonic disturbances. The conundrum, therefore, would read thus: A rock-basin ho:luwed out by erosion, and provided with a narrow outlet contemporaneously or later by the same force.

Soon the suspicion comes that the bulk of a karrier is a younger formation than the substance of the walls of the cañon. A likely explanation is afforded by the hypothesis of a Dandushka glacier, which left behind at different epochs a succession of terminal moraines; but I think that there is a simpler solution.

I believe that the barriers are preserved strips of huge masses of débris which once overwhelmed the valley frum one side, and that the gorges are cut through the projecting ends of ridges. A valley somewhat deeper than the present Dandushka valley, but otherwise almost exactly corresponding to it, received from the east a large supply of detritus, by which it became buried nearly throughout its entire length. The new level thus created we may assume to have been a little higher than the present barriers. This mass of débris sloped, of course, towárds the west, and pressed the river against the opposite mountain-side. Excavating its bed, the stream cut through some of the bulging projections and promontories embedded in the softer material. The rocky channel acted as a natural river correction, and protected the earth accumulated against it from being washed away. Above and below these points, however, the process of clearing out followed the usual course, and in the intermediate basins the original profile of the valley is being approximately restored. A barrier and a cañon constitute a geographical symbiusis; they owe each other their origin and continued existence.

In Fig. 5 (see map) I have tried to show how one may imagine the consecutive vertical and horizontal displacement of the river. I shall now proze my assertions.

A direct evidence that the detritus has come from the right is the inclination of the slope. But as inherent probability no inference could ve better than that drawn from the orographical formation of the neighbourhood. We have in the west the face of a long wa!l-in other 
words, a small supply of the products of disintegration-and opposite to it the outlets of a group of mountains. This is also illustrated by the fact that the Dandushka receives no tributaries from the left. That the accumulations once filled the greater part of the valley is shown by bits of terraces preserved hero and there in sheltered positions, e.g. between two ribs of roek, etc.

Against my own antithesis - the Dandushka glacier-I might propound the question why a cause acting in the direction of the valley should not have kept a better balance between the two banks, seeing that the gorges are almost entirely restricted to the left side.

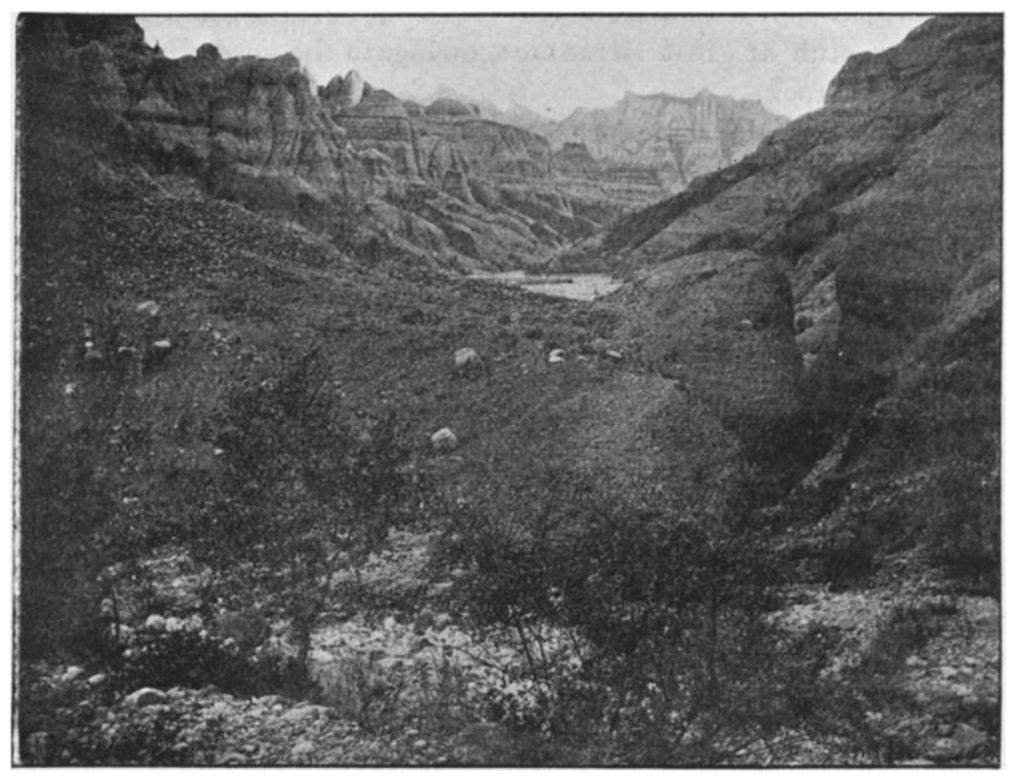

A BARRIER.

The proof that the hard conglomerate does not reach far into the barrier could best be brought by an excavation, but since such an experiment is costly, I must rely upon circumstantial evidence. Solid conglomerate never crops out anywhero near the middle of a bar. Some of the barriers show a succession of bexutiful level terraces, as I have intimated by the contour lines in Fig. 2.

At the cañon the barrier is always narrowest, broadening out towards the mountain and merging into its slopes with a long curved outline. This outline shows the range within which the earth is safe against being washed a way; in other words, the "protected area" of a barrier. If, as in Fig. 4, only a short distance intervened between two gorges, the river had not sufficient room to reach the opposite side of the valley. 
Therefore a curved wall of débris connects one barrier with the other. The protected areas overlap.

In Fig. 5 one sees how a little stream ( $c d$ on the map) has dug itself lengthwise through a barrier. Its high steep banks of hardened mud and gravel are innocent of rock, and only its entrance into the main cañon is effected through a cleft in the side wall. This is repeated by the Safet-Darya, which also, before its entranc e into the "Iron Gate," shows nothing but gravel banks, 80 feet high, on either side. A barrier in profile is shown in Fig. 3. The mainstay of the dam, the block of solid conglomerate, is generally exposed to some extent. Its summit is often quite free, and then has caused a notch to appear, which shows that here the atmospheric influences have acted on the loose stuff at great advantage, owing to the good sliding surface offered by the rock.

The shape of this bare projection affords a clue to the outline of the hidden portion. In the case of narrow barriers, the ends of small ridges have been sawed through, but the long cañons have "sliced off" big pieces from the mountain-side. The same principle is observed when microscopical sections are obtained from specimens embedded in wax (Fig. 2).

All the foregoing conclusions are supported by a phenomenon, which can best be studied between bars 1 and 2 . There the river runs through a low stone gutter 30 feet loug, which has on the right side a thin wall only 3 or 4 feet high. The difference in level between this channel and the surrounding plain is so small as to escape the eye. Thus the river apparently follows some inexplicable whim, selecting a narrow rigid groove in preference to the wide expanse of ground at its disposal.

Two similar formations are below the sixth barrier. From the point of view of evolution, they are the beginning of cañons. Various reasons lead me to think that the original bottom of the valley has not yet been reached, and I have expressed this by the line bc in Fig. 1. As to the causes of the great accumulation of detritus, I think that possibly a glacier may have been responsible for it. The traces of glacial corrosion cannot be supposed to be preserved long in a crumbling material like conglomerate. Only where quickly covered up by some time-resisting deposit, they would have a chance of being handed over to posterity.

A reliable witness is, perhaps, the great boulder which I discovered at the junction of Safet-Darya and Dandushka. Its size is about 80 cubic feet, and it rests with one of its angles on the clean rock slab over which the water of the Safet-Darya runs into the other river. Its surface shows numerous short and irregularly grouped scars, and the assumption is not too risky that it has been brought there by the ground moraine of an ice-age glacier of Hazrat-Ishan. 
After having continued our investigations to the middle of October, we had to think of the homeward journey. Before, however, finally leaving East Bokhara, my wife and myself made a trip to Muminabad, Kulab, and Sajat, pushing as far as the little Russian frontier-post of Parkhar, in the beautiful and idyllic plain of the Sayat-Darya. Here we have a pleasing combination of pasture, park, swamp, and impenetrable jungle. The reeds swarm with pheasants, and every pool of water is the abode of numerous waterfowl. The tracks of the tiger are frequently seen, but I waited four consecutive nights without getting a shot. Returning to Safet-Darya, we found a snowstorm raging in the Yakh-Su valley, and, arriving at the Russian colony, found the place buried in snow. These signs of approaching winter warned us not to delay our start. On November 4, therefore, we left, following our previous route as far as Ak-rabat. Here we struck northwards, and travelled by way of Shahr-i-ziabs and Kitab to Samarkand, thus bringing to a close a most interesting and instructive journey.*

After the reading of the paper, the following discussion took place:-

Mrs. Rickmers : I have often been asked how I bore the hardships of the journey just described by my husband, and perhaps this is a good opportunity for saying a few words on the subject.

In the first place, well-meaning friends did me unconsciously, perhaps involuntarily, a good service by drawing such harrowing pictures of the discomforts to be endured, that realization, as usual, fell far short of anticipation. My path from Batum to Bokhara was so strewn with their counsels and warnings that it was not their fault if, by the time I reached the Khanate, I had not a vivid premonition that we should die of thirst in the desert, or be massacred in some mountain fastness by the inhabitants. Even the secret hope I indulged that some mild form of adventure might be our fate was doomed to disappointment. Nothing more exciting than an occasional encounter with native dogs ever befel us.

As to the discomforts of the journey, they were really very trifling after all. Dress could fortunately be regarded with indifference, and this, together with the constancy of the climatic conditions, simplified matters considerably. Constant exercise in the open air is conducive to wholesome fatigue, and I have often rested better on the mud floor of a Bokhara hovel after a long day's march than amid all the refinements with which Western civilization woos the god of sleep.

Open-air travel suggests another consideration. The leisurely march on horseback enables the traveller to see and take in the details of the country through which he is fassing. Western methods of travel, in proportion as they have gained in speed, have lost in interest. The traveller borne through space at the rate of 60 miles an hour, sees but half the landscape through which he travels, an', as often as not, passes through the fairest regions at night. When he wakes in the morning, after a somewhat disturbed night's rest, it is, at best, amid a good deal of discomfort that he performs his morning toilet. Not so in Bokhara; our quarters there were

* I have just received the 'Jahrb. K. K. Geol. Reichs-Anstalt' (Wien, 1898), B. 48, H. 3 and 4, where A. Bittner describes some of the fossils collected by Dr. von Krafft during his excursion to Daswas. There are several new species. Some strata near Ravnau are practically identical with the Werfener Schiefer of the Alps. 


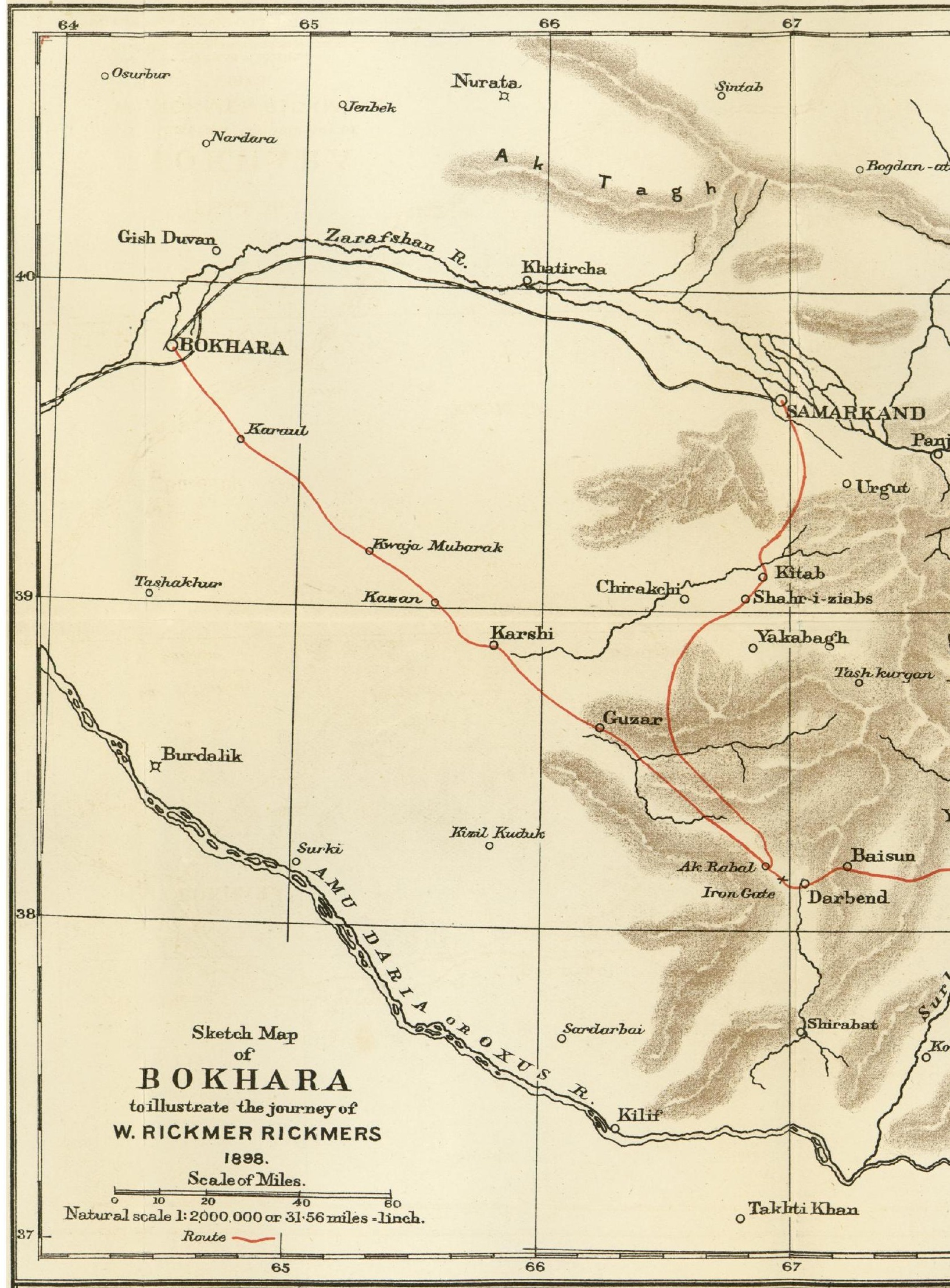

Fig.1.

Fig. 2.

This content downloaded from 132.203.227.63 on Sat, 07 May 2016 05:54:47 UTC All use subject to http://about.jstor.org/terms 
